\title{
BONE AND JOINT CHANGES IN PARAPLEGIC MEN*
}

\author{
BY \\ V. WRIGHT, R. D. CATTERALL $\dagger$, AND J. B. COOK \\ From the Rheumatism Research Unit, University Department of Medicine, Leeds, the Department of Venereology, \\ General Infirmary, Leeds, and Pinderfields Hospital, Wakefield, Yorks.
}

It is well known that in Reiter's disease there is an increased incidence of sacro-iliitis (Marche, 1950; Ford, 1953; Stanworth and Sharp, 1956; Murray Oates, and Young, 1958; Reynolds and Csonka, 1958; Wright, 1963). It has been suggested that this may be due to drainage via the prostatic venous plexus to the sacro-iliac joints (Grainger, 1959) or via the venous system described by Batson (1942) which passes from the prostate and seminal vesicles to lie in the lower part of its course directly over the sacro-iliac joints (Oates and Young, 1959). It has also been shown that in ankylosing spondylitis there is an increased incidence of chronic prostatitis as defined by clumps of pus or more than ten leucocytes in several half-inch microscopic fields of the prostatic secretion (Mason, Murray, Oates, and Young, 1958). The possibility is therefore raised that ankylosing spondylitis may be due to chronic genito-urinary infection (Romanus, 1953; Catterall, 1961).

One piece of evidence cited in favour of this view is that sacro-iliitis is said to occur in patients with paraplegia (Abel, 1950; Lodge, 1956). Mason and others (1958) felt that genital inflammation causing sacro-iliitis was a seductive hypothesis and the high incidence of sacro-iliac disease in male paraplegics, nearly all of whom may be expected to have chronic prostatitis, added support to the theory. This view was endorsed by a leading article in the British Medical Journal (1960).

Other changes described in paraplegic patients have included osteoporosis and soft tissue calcification. Lodge (1956), in an extensive radiological study, reviewed the films of 236 patients, and noted osteoporosis in 127. Three patients had fractures with pronounced new bone formation. Ectopic calcification was present in 33 per cent. between pelvis and knee, and occurred around the hips in

\footnotetext{
* Read in part at a meeting of the Heberden Society, February 26, 1965.

$\dagger$ Present address: The Middlesex Hospital, London, W.1.
}

eighteen. In a study of 35 cases (Abramson and Kamberg, 1949), osteoporosis was noted in six, and proliferative bone changes and soft tissue calcification about the hips and upper portion of the femur in seven. Others noted this soft tissue calcification (Miller and O'Neill, 1949), stating that it never occurred above the pelvis or below the knee, but showed a predilection for the medial femoral condyle. Heilbrun and Kuhn (1947) commented on the similarity to the Pelegrina-Steida syndrome. A detailed pathological study in eleven patients was done by Liberson (1953). Erosion of bone over pressure points, particularly the sacrum, greater trochanter, and ischial tuberosities, has been noted (Heilbrun and Kuhn, 1947; Lodge, 1956). Brailsford (1941) discussed the phases of Charcot's arthropathy and described some of the changes in paraplegics with a few illustrative case reports.

Most studies have been retrospective and have not attempted a clinical correlation. Little attention has been paid to articular manifestations. Although osteoporosis of the central skeleton has been described frequently, no reference has been found to peripheral bones and joints.

The present study was therefore undertaken to ascertain the nature of bone and joint changes in patients with paraplegia by a detailed clinical, radiological, serological, and bacteriological examination. Particular attention was paid to sacro-iliac joint changes and their relationship to the clinical type, course, extent, and complications of the paraplegia. A detailed investigation of genito-urinary infection was undertaken in these patients.

\section{Material and Methods}

Thirty-eight men who had been treated in the Paraplegic Unit at Pinderfields Hospital, Wakefield, were interviewed and examined by the authors. Some inpatients had been re-admitted for the treatment of decubitus ulcers, so that the series is selected and contains a relatively large number with ulcers. One author 
(J.B.C.) concerned himself with the type and extent of the paraplegia and undertook cystoscopy where indicated, one (V.W.) investigated the occurrence and nature of rheumatic complaints, and the third (R.D.C.) made a detailed examination of the genito-urinary tract.

Radiographs of the feet and sacro-iliac joints (anteriorposterior view) were taken in all patients. Radiographs of the spine were performed where the causative lesion so indicated. The serum albumin, serum globulin, serum uric acid, serum urea, and Waaler-Rose differential agglutination of sensitized sheep cells were assessed for all patients. In cases in which there was evidence of urethral discharge, an urethral smear was made and stained with Gram's stain before being examined microscopically. Culture plates and culture media for growing Trichomonas vaginalis were inoculated with samples of the discharge. In a number of cases digital examination of the prostate was carried out and prostatic massage performed. Specimens of prostatic fluid were examined microscopically, by culture, and on stained smears. The urine was examined by the two-glass test whenever possible and tested for albumen and sugar. The centrifuge deposit of a sample of urine was examined microscopically and by culture in every case. Intravenous pyelography was performed in a number of patients, and was included in the assessment of the genital tract. The results of cystoscopy were also considered when the status of the genito-urinary tract was being assessed.

The radiographs were read by two observers (R.D.C. and V.W.), without knowledge of the clinical history. The sacro-iliac joints were examined for sclerosis, erosion, and ankylosis. An overall assessment of sacro-iliac joint changes (s.i. changes) was made. The feet were examined for osteoporosis, which was graded according to the scale $0=$ no change, $1=$ doubtful, $2=$ mild,
3 = moderate, $4=$ severe, and further described as generalized or patchy. The spinal films were examined when available for features of spondylitis. Soft tissue calcification was sought particularly.

\section{Observations}

\section{Clinical Features of Paraplegic Patients}

The 38 males ranged in age from 9 to 64 years (mean $38 \cdot 1$ ). The paraplegia had been caused by injury in 33 patients (Fig. 1). Of the other five, one had disseminated sclerosis, one had Paget's disease, one had sub-acute combined degeneration of the cord, and one had an angioma of the lower part of the spinal cord. In the fifth patient the exact cause was not clear but, at operation, when laminectomy of the third dorsal vertebra was performed, thickened dura mater was found with granulation tissue, suggesting pachymeningitis.

The paraplegia was complete in 24 and partial in fourteen patients. It was mainly motor in six patients, mainly sensory in two, and combined in thirty. It was longstanding in seventeen patients, having been present for between 3 and 5 years in nine and from 6 to 10 years in eight. Eight patients had been affected for 1 to 2 years, six for 6 to 12 months, and seven for less than 6 months. The cord lesion was in the cervical region in four, in the dorsal region in eighteen, and in the dorso-lumbar region in five; eleven had cauda equina lesions. The majority were admitted to the special unit immediately, but in eleven cases admission was delayed

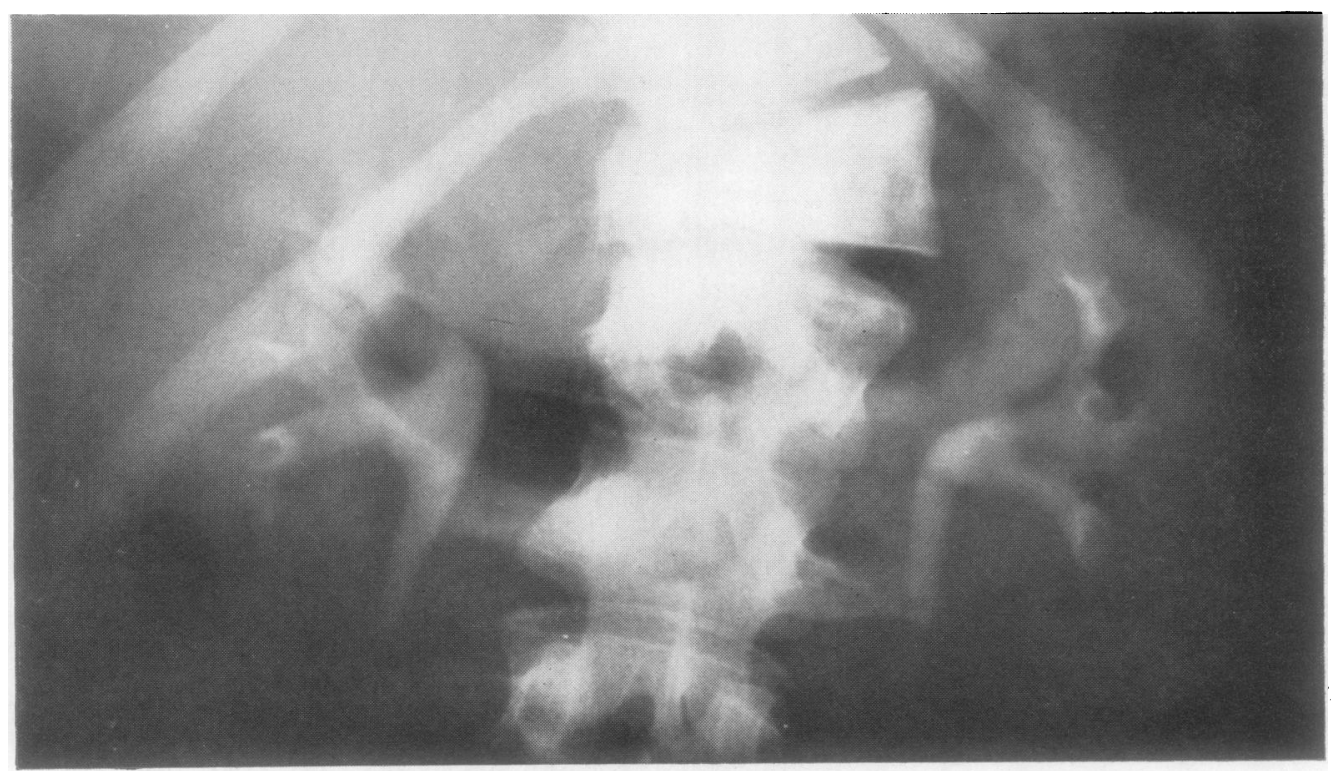

Fig. 1.-Crush fracture with wedging of first lumbar vertebra showing on i.v.p. examination. 
with a consequent delay in mobilization. Plating was done in thirteen traumatic cases (Figs 2 and 3), and laminectomy was performed in the case with pachymeningitis.

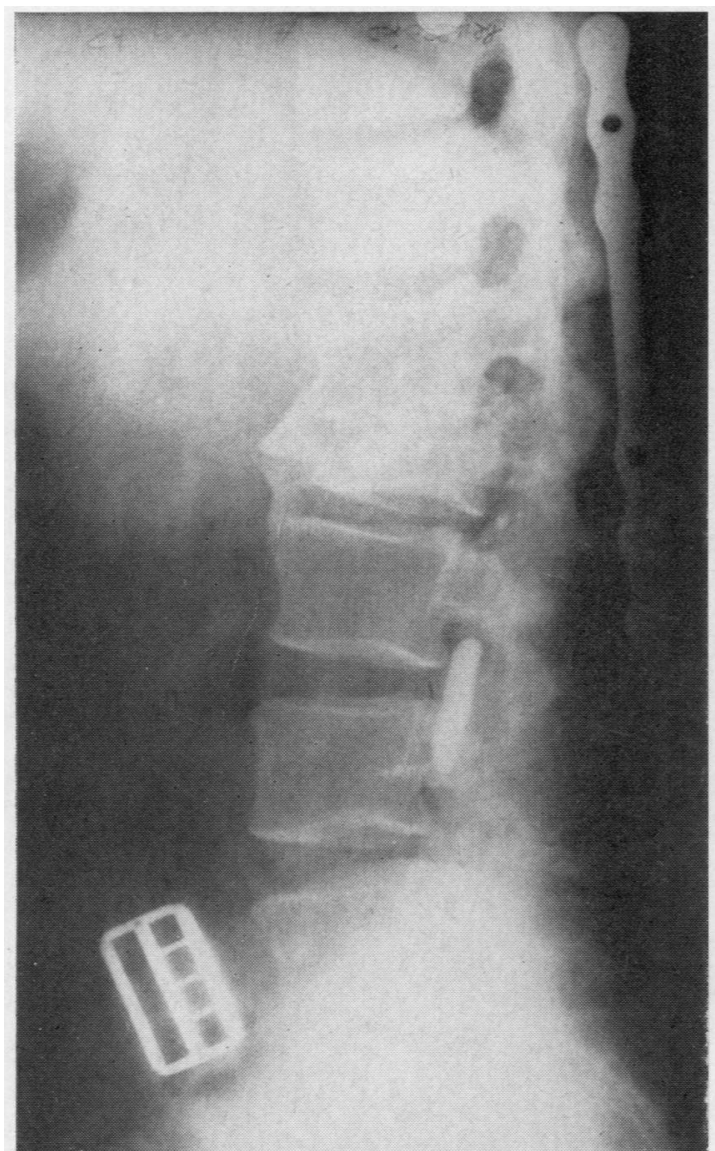

Fig. 2.-Lateral lumbar spine radiograph taken post-operatively, showing crush fracture of second lumbar vertebra and plate inserted.

\section{Complications of the Paraplegia}

Decubitus ulcers were present over the sacrum in seventeen patients, over the hips in nine, over the ankle in four, and over other sites such as the elbow, heel, and big toe in five. Severe ulceration may involve joint cavities or expose bony surfaces, but in none of the present series were the ulcers sufficiently severe to do this. Minor ulcers, not exceeding $2 \mathrm{~cm}$. in diameter, often resulted from abrasions of appliances such as calipers. Ulceration exceeding this size occurred in thirteen patients (Fig. 4, overleaf).

Significant ulcers occurred most frequently in those patients who were confined to bed for the longest periods. Only 20 per cent. of patients who were up

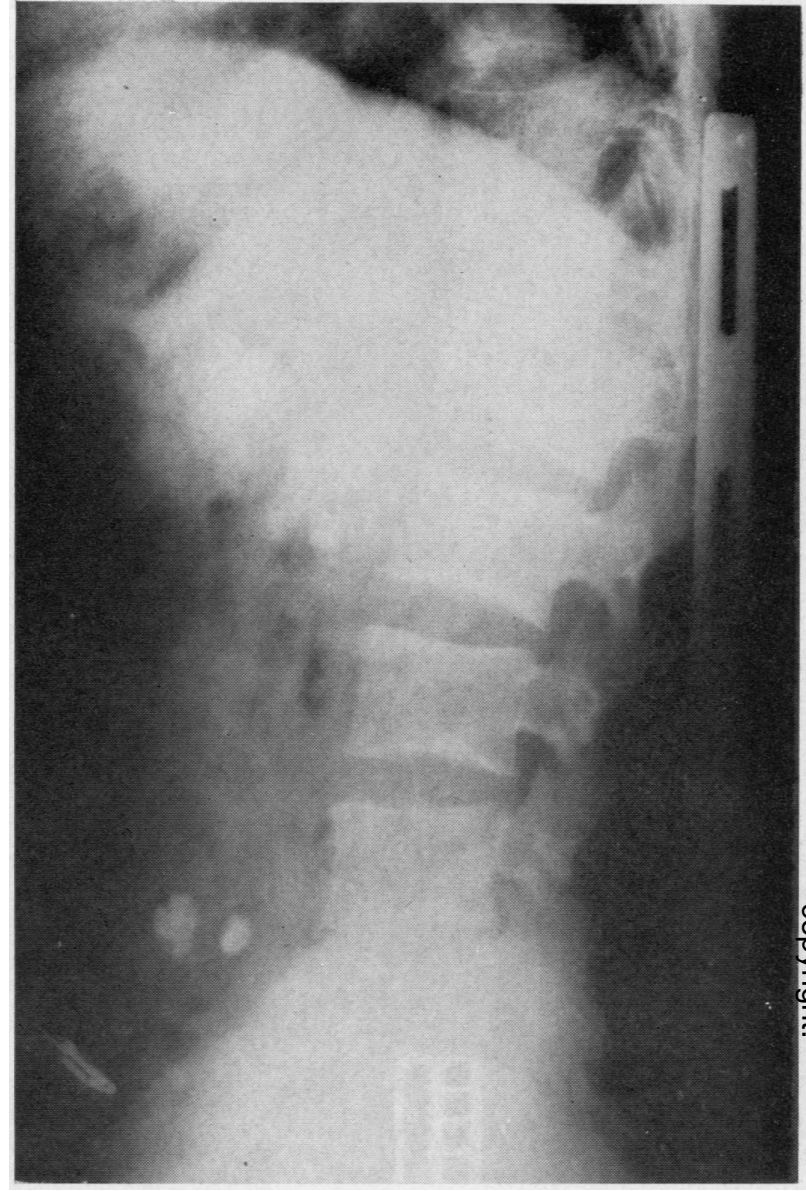

Fig. 3.-Lateral lumbar spine radiograph, showing crush fractures of first lumbar vertebra. At operation the spines and laminae of the twelfth dorsal and first lumbar vertebrae were removed, and two plates were put on either side and fixed to the spines of the eleventh and second dorsal vertebrae.

within 3 months had such ulcers compared with 80 per cent. of those in bed for 4 to 6 months, and they were present in all three patients who had been in bed for over 7 months. Ulcers were present three times as often amongst patients who had both motor and sensory damage than amongst those who had either motor or sensory nerves predominantly affected (11 of 30 compared with 1 of 8 respectively). The level of the cord lesion made no significant difference to the incidence of ulcers. There was no evidence that there was increased liability to ulceration with advancing age. The highest incidence occurred amongst the ten males between 16 and 25 years old, five of whom had significant ulceration. 


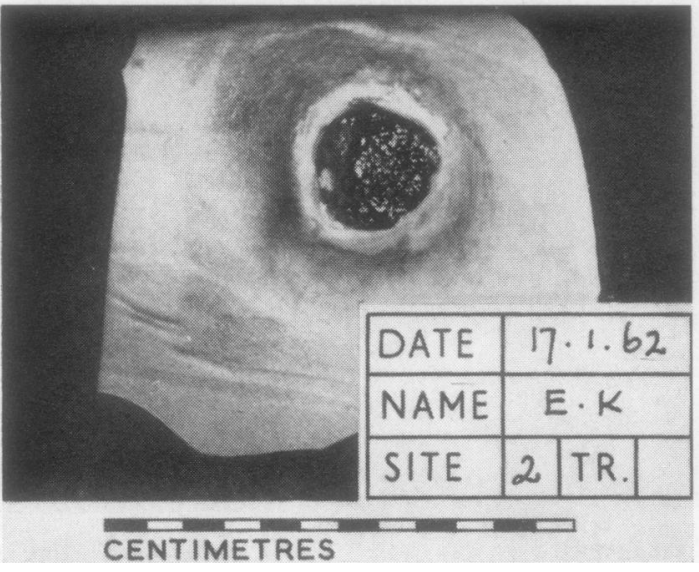

Fig. 4.-Moderate decubitus ulceration over greater trochanter.

Oedema always followed the initial period of bed rest, when the patient first assumed an upright posture; interestingly enough this usually subsided spontaneously but eleven patients had persistent oedema at the time of examination.

Permanent contractures were rare. They were present in only three patients, two in severe and one in mild degree. This low incidence was doubtless due to the fact that the patients were drawn from a special unit.

Loss of weight was estimated in 27 patients. Seven showed no loss, seven showed a loss of up to 10 per cent. of their original weight, seven from 11-20 per cent., and six over 20 per cent.

\section{Genito-urinary Findings}

Some abnormality of micturition was present in all patients. In only one had there been suprapubic drainage. The others required catheterization at some stage and urinary infection during the course of the illness was universal. At the time of examination urinary infection, as judged by the two-glass test and examination of the centrifuged deposit of urine, was present in 25 patients. Assessment of chronic genital infection was made by examination of a smear of urethral discharge when this was present. It was not always possible to perform prostatic massage on these patients owing to the reflex defaecation and urination which frequently occurred with this procedure. The degree of infection was assessed by the number of clumps of pus cells in a smear of the urethral discharge; it was absent in twelve patients, mild in fourteen, moderately severe in nine, and severe in three. Culture of the urethral discharge showed no growth or organisms in nine patients, streptococci in five, staphylococci in twelve, diphtheroids in eleven, and coliform organisms in seven. Other organisms were grown in twelve patients and included non-pathogenic Neisseria (7), anthracoids (4), and B. proteus (2). Cystoscopy was performed in seventeen patients and bladder calculi were found in six.

\section{Articular Manifestations}

Examination of the peripheral joints revealed Heberden's nodes in two patients, pain in the right shoulder in four (with recurrent dislocation in one), swelling of a knee in two (with local warmth in one), and contractures in three. Restriction of ankle movement occurred in the majority of patients, being more severe in fifteen; it was, however, very difficult to assess true passive movement at the ankle because of spasticity and fifteen may be an excessive estimate of the number with periarticular changes producing limitation of movement.

Osteoporosis of the feet was present in 34 patients, being generalized in eight and patchy in sixteen. This will be discussed in more detail later. Calcification of the soft tissues was seen radiologically in two patients (Fig. 5).

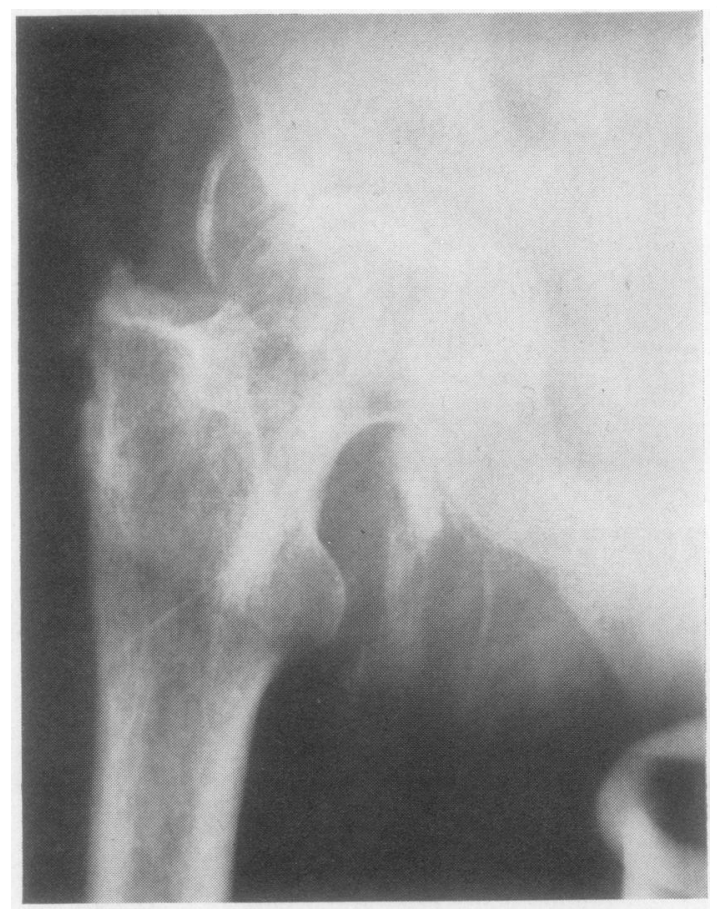

Fig. 5.-Radiograph showing ectopic bone around greater trochanter and soft tissue calcification above and below neck of the femur. 
An interesting finding was clubbing of the digits in eleven patients. Four patients had clubbing of the fingers and eight had clubbing of the toes. Erythema around the base of the nails was present in these patients, being marked in five.

Clubbing was not found in any of the thirteen patients with paraplegia of less than one year's duration. The incidence in the others was 44 per cent., and this was substantially the same in those with a duration of 1 to 2 years (50 per cent.), three to 5 years ( 44 per cent.), and 6 to 10 years ( 38 per cent.). Clubbing was more frequent in patients with significant decubitus ulcers (8 of 13), compared with those in whom ulceration was minor or absent (3 of 25). The incidence of clubbing with each site of ulceration was sacrum 29 per cent., hip 44 per cent., ankle 50 per cent., other sites 50 per cent. Clubbing was twice as common when persistent oedema was present ( 5 of 11 patients) as in those without oedema ( 6 of 27). There was no correlation with the level of the spinal cord lesion and none with genito-urinary infection.

\section{Sacro-iliac Joint Changes}

These were seen radiographically in twelve patients (Fig. 6).

No patient showed major erosions of the sacroiliac joints of the type seen with ankylosing spondylitis, Reiter's syndrome, or ulcerative colitis (Fig. 7, overleaf), and no patient showed complete ankylosis of the joints. No patient had moderate or severe sacro-iliitis as depicted in the Atlas of Standard Radiographs (Council for International Organizations of Medical Sciences, 1963).

Five patients with sacro-iliac changes were under 35 years of age, and seven were between 36 and 65 years. There was no relation to age when analysed by decades.

The relation of sacro-iliac changes to duration of paraplegia is shown in Table I (overleaf).

23 per cent. of paraplegics of less than 12 months duration had sacro-iliac changes, compared with 36 per cent. of those of more than 12 months' duration. There was little difference in incidence among those of the shortest compared with those

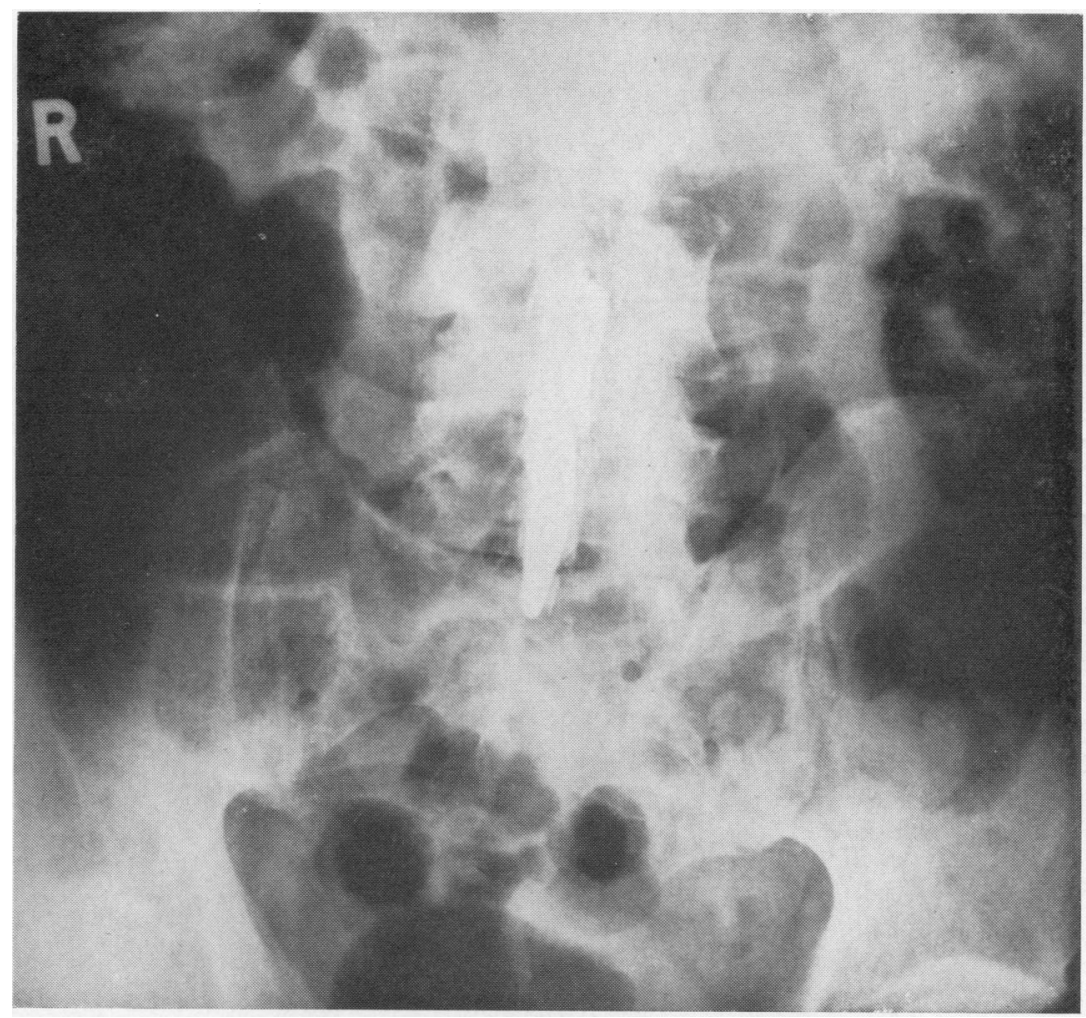

Fig 6.-Sacro-iliac changes shown radiographically (myodil remains in the spinal column). 


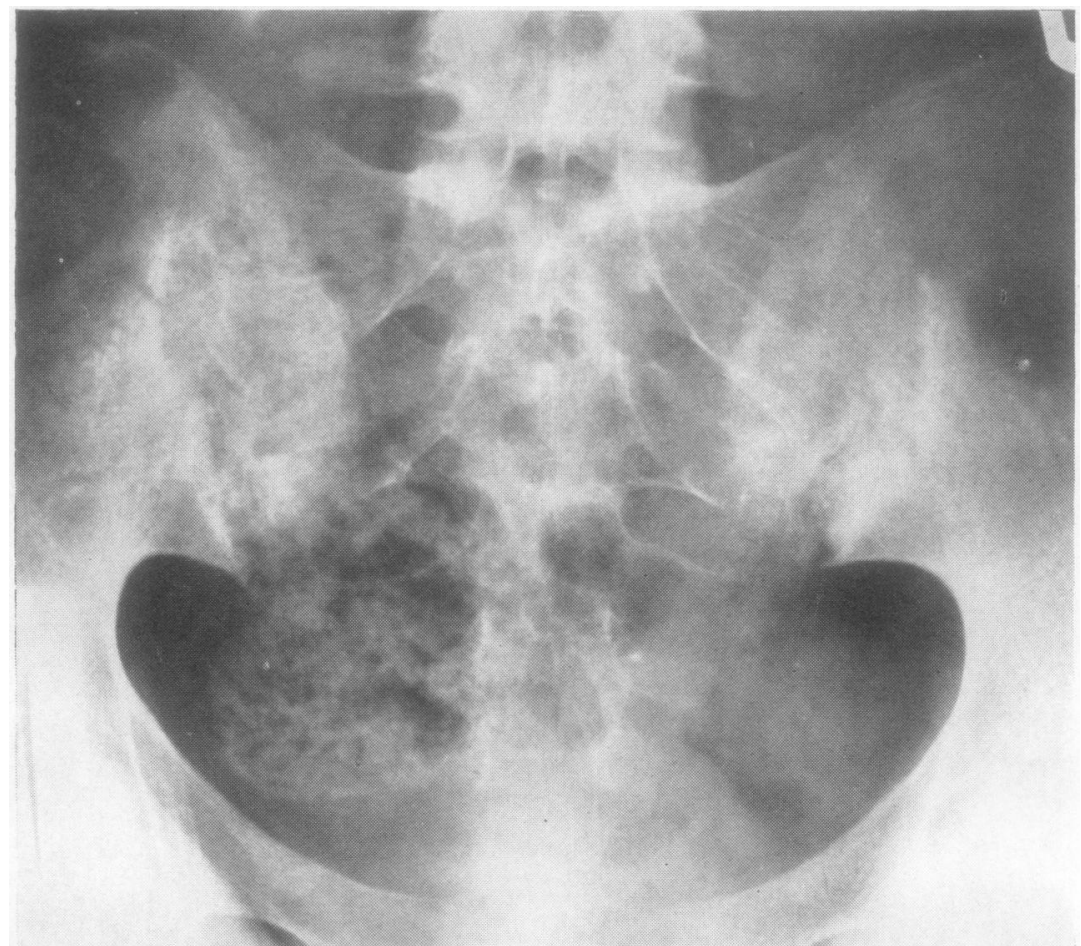

Fig. 7.-Sacro-iliitis in a patient with ulcerative colitis. Note bilateral erosive changes.

TABLE I

SACRO-ILIAC CHANGES RELATED TO DURATION OF PARAPLEGIA

(Percentages in Parentheses)

\begin{tabular}{|c|c|c|c|c|c|}
\hline \multirow{2}{*}{\multicolumn{2}{|c|}{ Sacro-iliac Changes }} & \multicolumn{4}{|c|}{ Duration of Paraplegia (yrs) } \\
\hline & & $0-1$ & $1-5$ & $6-10$ & Total \\
\hline $\begin{array}{l}\text { Present } \\
\text { Absent }\end{array}$ &. & $10^{3(23)}$ & $10^{7(41)}$ & $2(25)$ & $\begin{array}{l}12 \\
26\end{array}$ \\
\hline Total & $\ldots$ & 13 & 17 & 8 & 38 \\
\hline
\end{tabular}

of the longest duration. Indeed, one patient with very early paraplegia (less than 3 months' duration) had sacro-iliac changes, but analysis of patients in whom paraplegia was caused by injury showed that 17 per cent. with a duration of less than 1 year had sacro-iliac changes compared with 33 per cent. of those with a duration of more than 1 year.

There was a marked increase in the incidence of sacro-iliac changes when admission to a special unit was delayed (Table II). Moreover, of the three patients bed fast for over 6 months, two had sacroiliac changes.

The incidence of sacro-iliac changes related to general management of the paraplegia was assessed
TABLE II

SACRO-ILIAC CHANGES RELATED TO DELAY IN ADMISSION TO A SPECIAL UNIT AND TIME OF CONFINEMENT TO BED (Percentages in Parentheses)

\begin{tabular}{|c|c|c|c|c|c|}
\hline \multirow{2}{*}{$\begin{array}{c}\text { Sacro-iliac } \\
\text { Changes }\end{array}$} & \multicolumn{2}{|c|}{ Admission } & \multicolumn{3}{|c|}{ Time in Bed (mths) } \\
\hline & Immediate & Delayed & $0-3$ & 4-6 & $7+$ \\
\hline $\begin{array}{ll}\text { Present } & . \\
\text { Absent } & \ldots\end{array}$ & $20(26)$ & $\begin{array}{l}5(45) \\
6\end{array}$ & $21^{9(30)}$ & $4^{1}(20)$ & $2(67)$ \\
\hline Total & 27 & 11 & 30 & 5 & 3 \\
\hline
\end{tabular}

(Table III). Routine management usually meant that the patient was mobilized to some extent within 3 months of admission. It will be seen that opera-

TABLE III

SACRO-ILIAC CHANGES RELATED TO MANAGEMENT OF PARAPLEGIA

\begin{tabular}{|c|c|c|c|c|c|c|}
\hline \multirow{2}{*}{\multicolumn{2}{|c|}{$\begin{array}{c}\text { Sacro-iliac } \\
\text { Changes }\end{array}$}} & & \multicolumn{4}{|c|}{ Treatment } \\
\hline & & & Routine & Operation & $\begin{array}{c}\text { Delayed } \\
\text { Mobilization }\end{array}$ & Total \\
\hline $\begin{array}{l}\text { Present } \\
\text { Absent }\end{array}$ & $\begin{array}{l}\ldots \\
\ldots\end{array}$ & $\begin{array}{l}\ldots \\
\cdots\end{array}$ & $\begin{array}{r}4 \\
13\end{array}$ & $\begin{array}{r}4 \\
10\end{array}$ & $\begin{array}{l}4 \\
3\end{array}$ & $\begin{array}{l}12 \\
26\end{array}$ \\
\hline Total & $\ldots$ & .. & 17 & 14 & 7 & 38 \\
\hline
\end{tabular}


tion on the spine made little difference to the incidence of sacro-iliac changes. There was a marked increase in such changes, however, in those patients in whom full mobilization had been delayed.

Sacro-iliac changes were not related to the presence or severity of genital infection as assessed by smear of the urethral discharge (Table IV). Indeed there was a higher incidence of sacro-iliac changes in those without infection (58 per cent.) than in those with it (19 per cent.) judged by this method.

TABLE IV

SACRO-ILIAC CHANGES RELATED TO GENITAL INFECTION

\begin{tabular}{|c|c|c|c|c|c|c|}
\hline \multirow{2}{*}{$\begin{array}{c}\text { Sacro-iliac } \\
\text { Changes }\end{array}$} & \multicolumn{6}{|c|}{ Genital Infection } \\
\hline & & Absent & Mild & Moderate & Severe & Total \\
\hline $\begin{array}{l}\text { Present } \quad \ldots \\
\text { Absent }\end{array}$ & . & $\begin{array}{l}7 \\
5\end{array}$ & $\begin{array}{r}2 \\
12\end{array}$ & $\begin{array}{l}2 \\
7\end{array}$ & $\begin{array}{l}1 \\
2\end{array}$ & $\begin{array}{l}26 \\
12\end{array}$ \\
\hline Total & & 12 & 14 & 9 & 3 & 38 \\
\hline
\end{tabular}

Using the two-glass test as an index of urinary infection, 24 per cent. of the 25 patients with infection had sacro-iliac changes, compared with 46 per cent. of the thirteen patients without infection. Sacroiliac changes were not related to the organisms cultured, or to the presence of bladder calculi.

Table V demonstrates that sacro-iliac changes were not related to the presence or location of skin ulcers. In particular it should be noted that there was a higher incidence of sacro-iliac changes in patients with minor ulceration than in those with significant ulcers, and that sacro-iliac joint changes were less frequent in patients with ulcers over the sacrum.

There was no relationship between sacro-iliac changes and clubbing, contractures, weight loss, or restriction of ankle movement.

\section{Lumbar Spine}

Radiographs of the lumbar spine were available in 26 patients, none of whom showed evidence of spondylitis. In particular, no ligamentous calcification was seen. On none of the films of the sacroiliac joints was there any evidence of involvement associated with the lower lumbar vertebrae. One patient, a man aged 64 years, had marked osteophytosis, particularly prominent at the fourth lumbar vertebra. Similar changes were seen in the cervical spine.

\section{Osteoporosis}

Radiographs of the feet were graded for osteoporosis in 35 of the 38 patients in the study. In one patient the film could not be traced and two films were not good enough to permit assessment. Some degree of osteoporosis was present in all except one, and a moderate or severe degree in 23 patients. For the purpose of analysis these two grades have been combined and called "pronounced osteoporosis". Osteoporosis was generalized in eight patients and patchy in fifteen. Examples of these changes are shown in Figs 8 and 9 (overleaf).

Of the six patients with paraplegia of less than 6 months' duration, only one showed moderate osteoporosis of the feet, one showed no osteoporosis, and in the other four it was mild. Of the 29 patients with paraplegia of longer than 6 months' duration, fourteen had pronounced osteoporosis (i.e. 48 per cent.). The incidence in paraplegia present for from 7 months to 2 years was 52 per cent. and in that of over 2 years' duration 43 per cent. It appeared, therefore, that pronounced osteoporosis developed soon after 6 months and that there was little change in the condition after this. Osteoporosis was not related to age; three of ten patients less than 25 years old had pronounced osteoporosis, compared with only three of twelve patients over 45 years old.

Generalized osteoporosis seemed to be related to the duration of the paraplegia. It occurred in only one of twelve patients with paraplegia of less than 12 months' duration, in one of eight with paraplegia present for 1 to 2 years, and in six of fifteen with paraplegia of over 2 years' duration.

TABLE $V$

SACRO-ILIAC CHANGES RELATED TO THE SITE AND SEVERITY OF SKIN ULCERATION (PERCENTAGES IN PARENTHESES)

\begin{tabular}{|c|c|c|c|c|c|c|c|c|c|c|c|c|}
\hline \multirow{2}{*}{\multicolumn{6}{|c|}{ Sacro-iliac Changes }} & \multicolumn{3}{|c|}{ Severity } & \multicolumn{4}{|c|}{ Site } \\
\hline & & & & & & Absent & Minor & Significant & Sacrum & Hip & Ankle & Other \\
\hline \multirow[t]{2}{*}{$\begin{array}{l}\text { Present } \\
\text { Absent }\end{array}$} & $\begin{array}{l}\cdots \\
\cdots\end{array}$ & . & $\begin{array}{l}\cdots \\
\cdots\end{array}$ & $\cdots$ & $\ldots$ & $\begin{array}{l}4(13) \\
9\end{array}$ & $\begin{array}{l}5(42) \\
7\end{array}$ & $\begin{array}{l}3(23) \\
10\end{array}$ & $13(31)$ & $\begin{array}{l}3(33) \\
6\end{array}$ & $2(50)$ & $2(40)$ \\
\hline & & Total & . & . & - & 13 & 12 & 13 & 17 & 9 & 4 & 5 \\
\hline
\end{tabular}




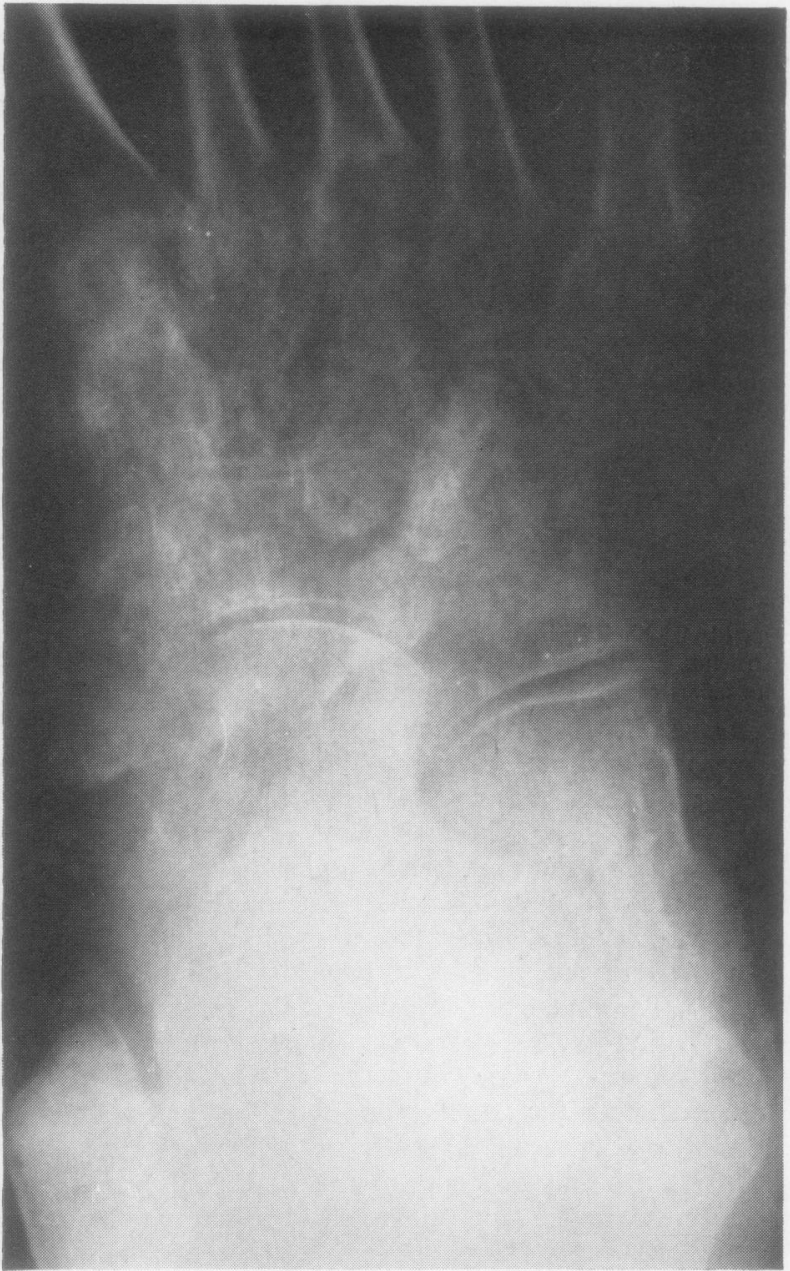

Fig. 8.-Severe patchy osteoporosis in tarsus.

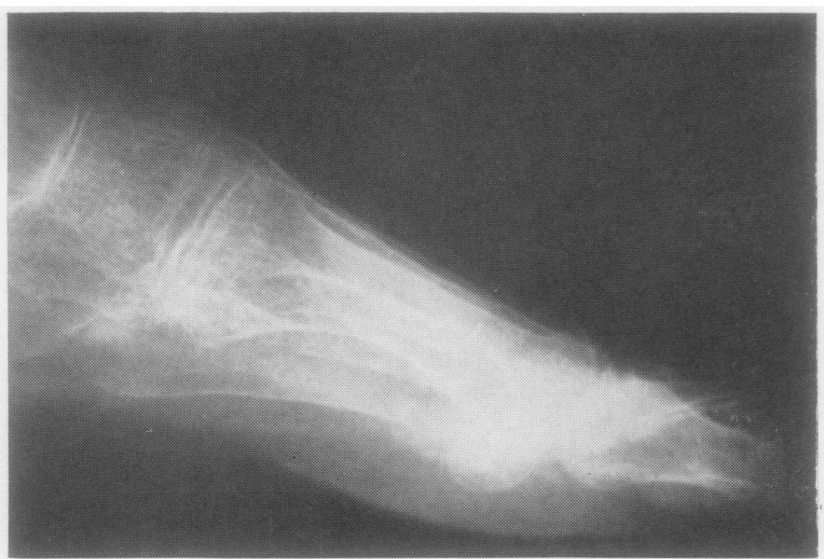

Fig. 9.-Generalized osteoporosis shown on lateral radiographs of foot.
There was some evidence that the longer patients were bedfast the more frequently pronounced osteoporosis occurred-it was present in 40 per cent. of those in bed for less than 3 months compared with 66 per cent. of those in bed for over 3 months, but the small numbers make these figures of doubtful significance. Delayed admission did not increase the incidence of osteoporosis; it was found in 28 per cent. of those whose admission was delayed, and in 42 per cent. of those admitted immediately on diagnosis. Both patients with severe contractures had moderate generalized osteoporosis.

There was a suggestion of a correlation with persistent oedema, in that 70 per cent. of patients with persistent oedema showed pronounced osteoporosis compared with 32 per cent. of those without persistent oedema. This correlation was also present with clubbing of the toes; osteoporosis was found in 57 per cent. of those with clubbing compared with 39 per cent. of those without clubbing, but the numbers are too small to draw conclusions.

54 per cent. of thirteen patients with severe restriction of ankle movement showed pronounced osteoporosis, compared with 36 per cent. of 22 patients without severe restriction.

There was no correlation of osteoporosis with the extent or location of skin ulceration, nor with weight loss, bladder calculi, genital infection, or type of treatment.

It was interesting that four patients with cervical lesions all showed only doubtful or mild osteoporosis, whereas pronounced osteoporosis was seen in half those with dorsal and lumbar lesions. This did not seem to be due to shorter duration of the disease, since tetraplegia had been present for 1 and 2 years respectively in two of the patients with cervical cord lesions.

\section{Blood Tests}

Two patients had positive differential agglutination tests (titres 16 and 256 respectively). Blood urea was normal except in one patient who had a slight elevation to $46 \mathrm{mg}$. per $100 \mathrm{ml}$. Serum uric acid was normal except in one patient with a level of $10 \mathrm{mg}$. per $100 \mathrm{ml}$.- this was not the patient with a raised blood urea. The serum globulin was raised in ten patients (the results are listed in Table VI, opposite).

\section{Discussion}

Relatively little has been written about the bone and joint changes in paraplegia and they find no mention in the excellent text-books on the rheumatic diseases (Hollander, 1960; Copeman, 1964). Two 
TABLE VI

RAISED SERUM GLOBULIN LEVELS IN TEN MEN WITH PARAPLEGIA

\begin{tabular}{c|c}
\hline Patient No. & Globulin $(\mathrm{g} . / 100 \mathrm{ml})$. \\
\hline 4 & $3 \cdot 5$ \\
7 & $4 \cdot 0$ \\
8 & $4 \cdot 6$ \\
10 & $3 \cdot 4$ \\
11 & $3 \cdot 4$ \\
16 & $3 \cdot 3$ \\
17 & $4 \cdot 3$ \\
22 & $4 \cdot 4$ \\
35 & $3 \cdot 4$ \\
37 & $3 \cdot 8$ \\
\hline
\end{tabular}

useful radiological articles have been published by Abel (1950) and Lodge (1956), but most studies have been retrospective and have not been correlated clinically. Much emphasis has been placed upon soft tissue calcification (Heilbrun and Kuhn, 1947; Roche and Jostes, 1948; Abramson and Kamberg, 1949; Miller and O'Neill, 1949; Storey and Tegner, 1955), and this was found in two of our patients in typical sites above the greater trochanter of the femur. This aspect has been well reviewed by Hardy and Dickson (1963).

Other complications of paraplegia are well recognized, such as the decubitus ulcers which in our study were found most commonly over the sacrum and hips. They were present most frequently in those who had been confined to bed for the longest periods and in those in whom both motor and sensory modalities were impaired. Some patients had been re-admitted to hospital for treatment of decubitus ulcers, which involves treatment in bed, sometimes for prolonged periods; this resulted in a greater incidence of ulceration in the present series than would be found in an unselected series of patients with paraplegia.

Oedema was persistent in eleven patients. This may have been connected with deep vein thrombosis, since it is known that this is a common complication of paraplegia (Philipps, 1963), and Tribe (1963) found that in sixteen patients who died within 2 months of paraplegia six had pulmonary embolism.

\section{Sacro-iliac Joint Changes}

Much interest has been aroused recently in the sacro-iliac joint changes found in patients with paraplegia and their possible aetiological significance in relation to ankylosing spondylitis (Mason and others, 1958; B.M.J., 1960). Abel (1950) reported an incidence of sacro-iliac joint changes as high as 61 per cent.; he felt that these were suggestive of ankylosing spondylitis. Lodge (1956) reported sacro-iliitis in a number of his patients. Abramson and Kamberg (1949), in a review of 35 cases, commented on the similarity of the changes to those of ankylosing spondylitis. A review of the films in these papers, however, raises the suspicion that these changes may not in fact be the same as those of ankylosing spondylitis or of the sacro-iliitis associated with Reiter's syndrome or ulcerative colitis.

In the present study the term "sacro-iliitis" has been deliberately avoided and "sacro-iliac joint changes" has been used so that the issue may not be pre-judged. The radiographs showed no major erosive changes of the sacro-iliac joints and in no joint was there complete ankylosis. We believe that the changes observed are distinct from those of ankylosing spondylitis and Reiter's syndrome. They are probably due to damage by the severe mechanical stresses to which the pelvis is subjected in this disease, acting on osteoporotic bone. In attaining mobility by the use of crutches, considerable stresses are placed upon the pelvis, and as the patients sit they do so upon unsupported bones and joints. It is interesting to note that Romanus (1953), in his monograph on ankylosing spondylitis, discussed sixteen patients with paraplegia; his description implies that he apparently had reservations about whether the changes he observed corresponded to those of ankylosing spondylitis.

There is little histological data available, but Abel (1950) obtained a biopsy from one patient. There was no joint space and no cartilage. The area of adjacent bone was very vascular and the cortex very thin. Microscopically the bone seemed markedly atrophic and surrounded by much marrow. There was only one questionable area of joint surface where the bone surface was quite ragged and denuded of cartilage. In particular, there was no pannus and the appearances were rather those of atrophied cartilage.

In view of the suggested relationship between the sacro-iliac joint changes of this disease and the chronic genito-urinary infection to which these patients are subject (Prather, 1949; Bors, Engle, Rosenquist, and Holliger, 1950), particular attention was paid to genito-urinary infection. Detailed examination of the genito-urinary system is not easy in paraplegic patients. Many of them are incontinent of urine, many have an indwelling catheter, and others wear a portable urinal to collect the urine. Assessment of the prostate by rectal digital examination is also difficult and frequently impossible, because the patient is unable to help in positioning himself, because the spastic paralysis of the lower limbs makes kneeling or bending forward impossible, and because prostatic massage sometimes provokes 
a type of "mass reflex", with penile erection, ejaculation, incontinence of urine, defaecation, and involuntary flexion of the legs. For all these reasons full evaluation of the condition of the genito-urinary tract was not always possible, but investigations enabled an assessment of genito-urinary infection to be made in every case. No correlation was found between the presence of infection or the type of infecting organism and sacro-iliac joint changes. We could find no evidence therefore from this study to support the hypothesis that sacro-iliitis in conditions such as ankylosing spondylitis occurs as a result of chronic genito-urinary infection, but we concluded that the sacro-iliac joint changes differ in the two conditions. Infection may still be the explanation, but this theory does not find support from the changes found in these patients with paraplegia.

Table VII summarizes the correlations that were made between sacro-iliac joint changes and various clinical parameters.

TABLE VII

FACTORS INFLUENCING INCIDENCE OF SACRO-ILIAC CHANGES

\begin{tabular}{|c|c|}
\hline Increased & Same \\
\hline $\begin{array}{l}\text { Delayed admission } \\
\text { Longer bedfast } \\
\text { Delayed mobilization }\end{array}$ & $\begin{array}{l}\text { Age } \\
\text { Duration of paraplegia } \\
\text { Level of c.n.s. lesion } \\
\text { Genito-urinary infection } \\
\text { Bladder calculi } \\
\text { Decubitus ulcers } \\
\text { Clubbing } \\
\text { Contracture } \\
\text { Weight loss } \\
\text { Restricted ankle movement }\end{array}$ \\
\hline
\end{tabular}

It is noteworthy that decubitus ulcers were not correlated either in severity or site with sacro-iliac joint changes. The ulcers were found most frequently over the sacrum and one explanation of the changes previously reported may have been that ulceration produced changes directly in the joints, since it is well known that such ulcers do produce erosions of bone over pressure points (Lodge, 1956). This suggestion, however, finds no support from the present study. The positive correlations were related to the delay in admission of patients to a special unit, delay in mobilization, and length of confinement to bed. This provides indirect evidence for the suggestion that the changes observed are not those of sacro-iliitis but result from mechanical stresses imposed upon osteoporotic bones surrounding the joints, since it is these very patients who are more liable to develop pronounced osteoporosis. We did not find any evidence of spondylitis among the 26 patients who had radiographs of the lumbar spine. Nor was any evidence of spondylitis in the lower lumbar vertebrae visible on the films of the sacro-iliac joints. The lack of correlation with duration of paraplegia, level of the central nervous system lesion, urinary tract infection, and calculi agrees with the observations of Abel (1950).

\section{Clubbing}

Of bone and joint changes the most significant clinically was clubbing. In eleven patients who showed clubbing paraplegia had been present for over 1 year. There was some suggestion that clubbing was related to the presence of decubitus ulcers, but it was not related to the site of this ulceration. A striking correlation was observed with the presence of persistent oedema.

\section{Osteoporosis}

This was found in all except one patient. Its presence has been frequently noted before, but attention has been confined almost exclusively to the pelvis and little attention has been paid to the peripheral bones and joints. Lodge (1956) noted osteoporosis in 127 of 181 films of the pelvis. Heilbrun and Kuhn (1947) noted osteoporosis in all of the 109 patients whom they reviewed.

We found pronounced osteoporosis of the feet in two-thirds of our patients. In eight the osteoporosis was generalized. It may be that this is the end-picture which manifests itself as a patchy osteoporosis in the earlier stages. Support for this suggestion is given by the fact that the correlation between osteoporosis and duration of the paraplegia was most marked in the patients with generalized osteoporosis. It is interesting that pronounced osteoporosis was a good deal more frequent after 6 months' duration of paraplegia, but there was little change in the incidence after this. It would appear that major osteoporosis developed soon after the 6-month period. Table VIII summarizes the clinical features that were correlated with osteoporosis and those that were not.

$$
\text { TABLE VIII }
$$

FACTORS INFLUENCING INCIDENCE OF OSTEOPOROSIS

\begin{tabular}{|c|c|}
\hline Increased & Same \\
\hline $\begin{array}{l}\text { Longer duration of } \\
\text { paraplegia } \\
\text { Longer bedfast } \\
\text { Severely restricted ankle } \\
\text { movement } \\
\text { Contracture } \\
\text { Persistent oedema } \\
\text { Clubbing }\end{array}$ & $\begin{array}{l}\text { Age } \\
\text { Delayed admission to hospital } \\
\text { Operation } \\
\text { Decubitus ulcers } \\
\text { Weight loss } \\
\text { Genito-urinary infection } \\
\text { Bladder calculi }\end{array}$ \\
\hline
\end{tabular}


Osteoporosis was more frequent with persistent oedema and with clubbing. This raises the possibility that the mechanism of "disuse osteoporosis", of which this would appear to be an example, is vascular. There is good evidence for believing that clubbing is related to vascular changes (Flavell, 1956). Our studies suggest that persistent oedema has a similar basis. None of the patients had a low serum albumin; there was no evidence of inflammatory changes, and the normal blood urea would suggest that renal function was not severely impaired. The most likely explanation of the oedema is that it too is vascular in origin. The correlation between both these features and pronounced osteoporosis provides some circumstantial evidence for the idea that the bone changes have a vascular basis. From other evidence Trueta (1964) concluded that the mechanism of disuse osteoporosis in other situations was predominantly vascular.

One possible explanation of persistent oedema in paraplegics is the occurrence of deep vein thrombosis. Tribe (1963) found that pulmonary embolism due to deep vein thrombosis was a common cause of death in paraplegia, and there is other evidence that it is more likely to occur in such patients (Philipps, 1963). This may be the underlying vascular abnormality in our patients.

\section{Blood Changes}

The most common abnormality encountered in the blood tests was a raised serum globulin. This is not surprising in view of the chronic infection in these patients. Although all had urinary tract infection at some time and there were bladder calculi in six, there was only one example of a raised blood urea, and that of mild degree. The serum uric acid was also raised in only one patient, and none had clinical evidence of gout. Two patients had a positive Waaler-Rose sheep cell agglutination test, one in quite high titre (256), but the incidence is not higher than has been encountered in the general population (Kellgren and Ball, 1959).

\section{Summary}

38 male patients with paraplegia have been studied. The paraplegia was caused by injury in 33 ; it was complete in 24 and had been present for over 2 years in seventeen.

The cord lesion was in the cervical region in four, in the dorsal region in eighteen, and at the dorso lumbar level in five, and there were cauda equina lesions in eleven. In eleven patients admission to a special unit was delayed. Operation was performed in fourteen. Decubitus ulcers were present in 25 , of which twelve were only mild. The ulceration was related to delayed mobilization, and occurred three times as frequently among patients who had both motor and sensory damage. Persistent oedema occurred in eleven patients. Permanent flexion contractures were present in three. Twenty patients of 27 in whom it could be ascertained showed loss of weight. Urinary infection, as judged by the twoglass test, was present in 25 patients. Examination of the urethral discharge showed evidence of infection in 26 patients. Cystoscopy revealed bladder calculi in 6 patients.

The bone and joint changes seen clinically and radiographically have been described. A striking feature was clubbing in eleven patients; this did not occur in patients with paraplegia of less than 1 year's duration, it was present more frequently with decubitus ulcers and was twice as common when persistent oedema was present. Pronounced osteoporosis of the feet was found in 23 of 35 radiographs examined, being generalized in eight and patchy in fifteen. Calcification of the soft tissues was seen in two patients.

Sacro-iliac joint changes were seen in twelve patients. These differed from the changes of sacroiliitis which are seen in patients with ankylosing spondylitis, Reiter's syndrome, and ulcerative colitis. It is suggested that these changes in cases of paraplegia are due to mechanical stresses in osteoporotic bones surrounding the joints. There was no evidence to connect the sacro-iliac joint changes with chronic genito-urinary infection, nor with decubitus ulceration. Sacro-iliac joint changes were found more frequently in patients whose admission to a special unit had been delayed, those who had been confined to bed for longer periods, and those in whom mobilization was delayed.

Osteoporosis was present in patients with paraplegia of longer duration, in those who had been confined to bed for longer periods, in those with severely restricted movement of the ankles, and in those who had persistent oedema and clubbing.

A raised serum globulin was the most common blood abnormality. A raised blood urea and a raised serum uric acid were each found in a single patient and a positive sheep cell agglutination test was found in two patients.

\section{REFERENCES}

Abel, M. S. (1950). Radiology, 55, 235.

Abramson, D. J., and Kamberg, S. (1949). J. Bone Jt Surg., 31A, 275.

Batson, O. V. (1942). Ann. intern. Med., 16, 38.

Bors, E., Engle, E. T., Rosenquist, R. C., and Holliger, V. H. (1950). J. clin. Endocr., 10, 381.

Brailsford, J. F. (1941). Brit. J. Radiol., 14, 320. 
Catterall, R. D. (1961). Lancet. 2, 739.

Copeman, W. S. C. (1964). "Textbook of the Rheumatic Diseases", 3rd ed. Livingstone, Edinburgh.

Council for International Organizations of Medical Sciences (1963). "The Epidemiology of Chronic Rheumatism", vol. 2, "Atlas of Standard Radiographs of Arthritis". Blackwell, Oxford.

Flavell, G. (1956). Lancet, 1, 260.

Ford, D. K. (1953). Ann. rheum. Dis., 12, 177.

Grainger, R. G. (1959). J. Fac. Radiol. (Lond.), 10, 138.

Hardy, A. G., and Dickson, J. W. (1963). J. Bone Jt Surg., 45-B, 76.

Heilbrun, N., and Kuhn, W. G. (1947). Radiology, 48, 579.

Hollander, J. L. (1960). “"Arthritis”, 6th ed. Kimpton, London.

Kellgren, J. H., and Ball, J. (1959). Brit. med.J., 1, 523.

Leading article (1960). Ibid., 1, 865.

Liberson, M. (1953). J. Amer. med. Ass., 152, 1010.

Lodge, T. (1956). Acta radiol. (Stockh.), 46, 435.

Marche, J. (1950). Rev. Rhum., 17, 449.

Mason, R. M., Murray, R. S., Oates, J. K., and Young, A. C. (1958). Brit. med. J., 1, 748.

Miller, L. F., and O'Neill, C. J. (1949). J. Bone Jt Surg., 31-A, 283.

Murray, R. S., Oates, J. K., and Young, A. C. (1958). J. Fac. Radiol. (Lond.), 9, 37.

Oates, J. K., and Young, A. C. (1959). Brit. med. J., 1,1013

Philipps, R. S. (1963). Paraplegia, 1, 116.

Prather, G. C. (1949). "Urological Aspects of Spinal Cord Injuries." Thomas, Springfield, Ill.

Reynolds, D. F., and Csonka, G. W. (1958). J. Fac. Radiol. (Lond.), 9, 44.

Roche, M. B., and Jostes, F. A. (1948). Amer. J. Surg., 75,633 .

Romanus, R. (1953). Acta med. scand., Suppl. 280.

Stanworth, A., and Sharp, J. (1956). Ann. rheum. Dis., 15,140 .

Storey, G., and Tegner, W. S. (1955). Ibid., 14, 176.

Tribe, C. R. (1963). Paraplegia, 1, 19.

Trueta, J. (1964). "The Dynamics of Bone Circulation" in "Bone Biodynamics", ed. H. M. Frost, pp. 245-258 (Henry Ford Hospital International Symposium, 1963). Churchill, London.

Wright, V. (1963). Ann. rheum. Dis., 22, 77.

\section{DISCUSSION}

Dr. V. Steinberg (London): Was prostatic massage performed on these patients?

Dr. Wright: Yes, in some, but after a patient has urinated and defaecated over you several times, the enthusiasm of even the most dedicated student of genitourinary conditions becomes damped.

Dr. M. WILKINSON (Perth): Does perhaps immobility allow normal age changes in the sacro-iliac joints to occur much earlier? While looking through a series of tomograms I could not really distinguish between many cases of rheumatoid arthritis and many elderly general medical cases without any joint disease. At autopsy one could see that there was bony fusion in many general medical patients.

Dr. F. M. ANDrews (Stoke Mandeville): Dr. Guttman has recently allowed me to consult the notes and radiographs of 100 of his patients with traumatic paraplegia of more than 5 years' duration. Of these 55 per cent. had changes in the sacro-iliac joints, usually unilateral, rarely bilateral. As Dr. Wright has found, there was no relationship at all between the presence of urinary infection and sacro-iliitis, but there was a correlation, significant at the 5 per cent. level, between the presence of sacral sores and sacro-iliitis, and there was a very strong association indeed between the combined presence of sacral sores and urinary infection with sacro-iliac disease. Twenty-two had sacral sores and urinary infection, and of these seventeen had elimination of the sacro-iliac joints.

DR. WRIGHT: This is interesting, but not what we found. Nearly all these patients get chronic genito-urinary infections at some time or other-this is no reflection on their care.

DR. F. M. ANDrews: I would add that, of the patients I have mentioned, 40 per cent. never had pus cells or bacteria isolated from their urine at any time.

DR. R. M. MASON (London): Since I have been quoted, I must say how much I enjoyed this paper. The word "seductive" was chosen with great care. This shows the value of hypothesis in scientific work-it leads to further testing. We now hope that Dr. Wright's hypothesis will also lead to further work.

DR. D. A. Brewerton (London): Was there any correlation between the level of lesion and the production of sacro-iliac disease?

DR. WRIGHT: No.

\section{Lésions osseuses et articulaires chez des hommes paraplégiques}

RÉSUMÉ

On étudia 38 hommes atteints de paraplégie. Celle-ci était accidentelle chez 33 d'entre eux, complète chez 24 d'entre eux et présente depuis plus de 2 ans chez 17 d'entre eux.

On décrit les lésions osseuses et articulaires du point de vue clinique et radiologique. La déformation noueuse (clubbing) était un phénomène frappant chez 11 malades; elle ne survenait pas chez des paraplégiques depuis moins d'un an, était présente plus souvent lorsqu'il y avait une escarre de décubitus et deux fois plus souvent en présence d'un oedème persistant. Une ostéoporose prononcée des pieds fut trouvée en 23 sur 35 radiographies examinées; elle était généralisée en 8 cas et inégale en 15 cas. La calcification des tissus mous fut observée chez 2 malades.

Des lésions articulaires sacro-iliaques furent observées chez 12 malades. Elles se distinguaient de lésions de sacro-iliite vue dans la spondylarthrite ankylosante, le syndrome de Reiter et la colite ulcérative. On pense que ces lésions des cas de paraplégie sont dues à des surcharges mécaniques dans les os ostéoporotiques autour des articulations. On ne trouva rien qui indique un rapport entre ces lésions articulaires sacro-iliaques et l'infection genito-urinaire chronique ou l'escarre de décubitus. Les lésions articulaires sacro-iliaques furent trouvées plus souvent chez les malades dont l'admission 
au service spécial avait été retardée, les alités pendant longtemps et les mobilisés trop tard.

L'ostéoporose fut présente chez des malades dont la paraplégie était prolongée, qui étaient alités pendant longtemps, dont le mouvement de la cheville était très restraint et qui avaient de l'oedème persistant et des déformations noueuses.

L'anomalie hématologique la plus commune fut la globuline sérique augmentée. L'urémie et l'uricémie furent trouvées chez un seul malade et la réaction de Waaler-Rose fut positive chez deux malades.

\section{Lesiones óseas y articulares en hombres parapléjicos}

\section{Sumario}

Se estudiaron 38 hombres con paraplejía, de origen accidental en 33, completa en 24 y presente desde más de dos años en 17 de ellos.

Se describen las lesiones óseas y articulares clínica y radiológicamente. El clubbing fué un fenómeno destacado en 11 enfermos; ausente en parapléjicos de menos de un año, se veía a menudo en los con úlceras de decúbito y con doble frecuencia en presencia del edema persistente. Una osteoporosis pronunciada de los pies se observó en 23 de las 35 radiografías examinadas; fué generalizada en 8 casos y desigual en 15 casos. La calcificación de los tejidos blandos se vió en dos enfermos.

Lesiones articulaires sacro-iliacas viéronse en 12 enfermos. Diferieron de las lesiones de sacro-iliitis observadas en la espondilartritis anquilosante, el síndrome de Reiter y en la colitis ulcerativa. Se sugiere que estas lesiones de los casos de paraplejía se deben a fuerzas mecánicas en los huesos osteoporóticos alrededor de las articulaciones. No se encontró evidencia alguna de relación entre estas lesiones articulares sacro-iliacas y la infección genito-urinaria crónica o las úlceras de decúbito. Las lesiones articulares sacro-iliacas fueron halladas más a menudo en enfermos cuya admisión en el servicio especial había sido demorada, en los que habían permanecido demasiado tiempo en cama y en los movilizados muy tarde.

La osteoporosis existió en enfermos con paraplejía prolongada, en cama por mucho tiempo, con movimientos del tobillo muy reducidos, con edema persistente y con clubbing.

La globulina sérica aumentada fué la anomalía hematológica la más frecuente. La uremia y la uricemia fueron encontradas en un solo enfermo y la reacción de Waaler-Rose positiva en dos. 